\title{
MELACAK JEJAK IMPLEMENTASI PENGEMBANGAN ENERGI ALTERNATIF DI PEDESAAN: STUDI KASUS TENTANG PENGEMBANGAN BIOETANOL BERBASIS SINGKONG DI JAWA BARAT
}

\author{
Anugrah Saputra \\ Universitas Budi Luhur, Jakarta \\ email:putra_alegro@yahoo.com
}

Paper Accepted: 19 Maret 2018 Paper Reviewed: 20-27 Maret 2018

Paper Edited: 01-15 April 2018 Paper Approved: 20 April 2018

\begin{abstract}
This study discusses the intervention of government policy through the policy of biofuels (BBN) based on cassava in rural areas. The government program intended to build an independent village by introducing renewable energy with a bioethanol energy program in the village by bring new knowledge and perspective to the local community about renewable energy issues. The struggle against the meaning and practice of alternative energy continues to roll in line with the various interests that color at the local level. This research was conducted using qualitative method with explorative descriptive format and conducted to reach description of adaptation to the implementation of alternative energy program in rural area. This research through data collected with interviews and document analysis. The research findings the government driven bioethanol programs are the sectoral ministry of ESDM, without involving other related institutions. Cassava-based alternative energy has not been able to encourage the progress of the village, due to the unchanged behavior of the community on cassava, land issues for cassava, technological constraints, and socio-economic conditions of bioethanol that are not formed. This results that program does not sustainable in the future .
\end{abstract}

Keywords: bioethanol, adaptation and strategy, sustainability

\section{PENDAHULUAN}

Penelitian ini bertujuan untuk menyelidiki adaptasi dan strategi penerapan pengembangkan energi alternatif di pedesaan. Hal itu terkait dengan kebijakan energi nasional mengenai penggunaan dan pengembangan bahan bakar nabati (BBN) yang dicetuskan oleh pemerintah pusat. Program ini dirancang oleh pemerintah untuk mengurangi ketergantungan terhadap energi fosil, sekaligus penciptaan lapangan pekerjaan di perdesaaan (International Energy Agency, 2008). Pengembangan energi ini juga selaras dengan tuntutan pengembangan energi baru terbarukan yang salah satunya berbasis tanaman.
Pemerintah memiliki program untuk mengembangkan bahan bakar nabati, di antaranya melalui Desa Mandiri Energi dan Kawasan Khusus Pengembangan BBN. Desa Mandiri Energi adalah program untuk membantu desa memenuhi kebutuhan energinya dari sumber lokal terbarukan seperti minihidro, tenaga matahari, biogas, dan biofuel dan pada saat yang bersamaan menciptakan lapangan kerja, menambah produktivitas dan mengurangi kemiskinan. Kawasan Khusus Pengembangan BBN adalah program dengan proyek pilot untuk memicu pengembangan $\mathrm{BBN}$ (Maulidia, 2009).

Pengembangan energi alternatif berbahan baku nabati ini salah satunya diselenggarakan di 
Desa Cibunar, Kabupaten Garut. Awal perkenalan ide energi alternatif di Desa Cibunar terjadi sekira pertengahan tahun 2007 ketika tanaman Jarak Pagar (jathropa) diperkenalkan oleh aktor dari luar desa yang berhubungan dengan aktor-aktor lokal yang aktif memegang peran di desa (seperti: ketua kelompok tani dan pengurus desa). Kegiatan ini tidak lagi berlanjut karena Jarak Pagar bukan tanaman budidaya dan tidak diminati oleh pengumpul biji untuk dijual kembali atau diolah.

Pada tahun 2009 kemudian diperkenalkan singkong sebagai bahan baku bioetanol melalui Program Desa Mandiri Energi (DME). Proses transfer pengetahuan dilakukan oleh Kementerian ESDM yang melibatkan Dinas Sumber Daya Alam Dan Pertambangan dan Pemerintahan Desa Cibunar Kabupaten Garut. Infrastruktur pabrik etanol pun dibangun dengan pasokan bahan baku etanol melalui ketua kelompok-kelompok tani dan petani yang dilibatkan untuk menanam bibit singkong.

Sejauhmana praktik energi terbarukan tersebut bertahan diukur lewat daya adaptasi dan strategi yang dilakukan oleh aktor-aktor yang terlibat didalamnya. Implikasi sosial ini menjadi pertanyaan lanjutan, lebih jauh lagi jawaban atas pertanyaan tersebut akan memperlihatkan apakah program BBN berbasis singkong sesuai potensi nyata di tingkat lokal. Tentu hal tersebut terkait dengan latar belakang suatu daerah seperti kondisi lahan, sosial-ekonomi, budaya, sumber daya manusia, dan teknologi itu sendiri. Pada penelitian ini dilihat bagaimana dinamika, pergeseran, dan sejauh mana program pengembangan energi alternatif berbasis $\mathrm{BBN}$ di pedesaan untuk kebutuhan masyarakat pedesaan saat ini perlu disikapi secara kritis dan disikapi di masa mendatang.

\section{METODE PENELITIAN}

Penelitian ini menggunakan metodologi kualitatif deskriptif dalam bentuk studi kasus (case study) yang bertujuan menggambarkan implikasi kebijakan energi alternatif di perdesaan yang memunculkan adaptasi dan strategi dari pelaku-pelaku lokal dengan pendekatan kualitatif. Untuk mendapatkan jawaban dari pertanyaan penelitian tersebut, awalnya dilakukan studi data sekunder melalui penelitian masyarakat di pedesaan secara umum dan khususnya yang berada di wilayah Jawa Barat. Riset lapangan kemudian dilakukan untuk melihat kondisi yang sebenarnya mengenai adaptasi dan implementasi bahan bakar nabati berbasis bahan baku singkong.

Eksplorasi dilakukan melalui pengamatan lapangan (field observation) dan pelaksanaan wawancara secara informal di lokasi riset dengan melibatkan para aktor dan pelaku di tingkat lokal mengenai kondisi desa dan isu-isu energi terbarukan. Isu-isu yang berkembang dan terjaring diharapkan menjadi perhatian yang meluas, tidak jarang kemungkinan disertai pertentangan pandangan, misalnya di lembaga-lembaga tempat para peneliti tersebut bekerja atau di level pemerintahan. Dengan teknik problematisasi demikian, menjadi terbuka ruang bagi para informan untuk mengungkapkan hal-hal yang terkait dengan kondisi sosial di lingkungan mereka masing-masing.

Penyelidikan deskriptif bertujuan untuk memberi gambaran tentang suatu masyarakat atau suatu kelompok orang tertentu, atau gambaran tentang suatu gejala atau hubungan antara dua gejala atau lebih (Miles dan Huberman, 1992). Adapun gejala sosial yang dideskripsikan secara sistematik dalam penyelidikan ini adalah proses dan bentuk relasi yang terjadi terkait pengembangan energi bioetanol yang telah dilakukan.

\section{HASIL DAN PEMBAHASAN}

\section{Pengetahuan Mengenai Singkong dan Perlakuannya}

Masyarakat Cibunar sudah mengenal singkong sejak dahulu. Ada pun jenis singkong yang dikenal penduduk lokal jenisnya yaitu, Sampeu Manehot (dagingnya berwarna putih), Sampeu Mentega (dagingnya kuning), dan Sampe Udi serta Sampeu Pedro (dagingnya pahit, tidak enak dikonsumsi langsung). Biasanya jenis singkong untuk konsumsi ditanam di tanah darat (kebun) tumpang sari bersama kacang tanah, kedelai, dan jagung. Singkong lebih banyak digunakan sebagai tanaman pelengkap ketika jagung atau kacang tanah gagal panen. Karena itu singkong lebih banyak digunakan sebagai makanan yang di olah sesuai dengan selera masing-masing konsumen. Kadar gula dan karbohidrat singkong dianggap tinggi, dan merupakan pengganti nasi.

Meski demikian, potensi pertanian lain yang banyak ditanam di desa antara lain: padi, jagung, kedelai, kacang tanah, ubi kayu dan cabai. Tanaman jagung dan kacang tanah lebih dipilih karena masa panennya cepat, sekitar tiga bulan. Usia tanam singkong bisa mencapai 6 sampai 8 bulan, sehingga komoditi itu sebenarnya tidak bisa dilihat secara cepat panen dan komersial. Kontrol petani terhadap kebun tidak dilakukan setiap saat, biasanya hanya untuk merawat kacang dan jagung dari hama dan pemupuknya.

Perlakuan terhadap singkong tidaklah menuntut perawatan dan pengelolaan yang khusus, karena ia bukan komoditi komersial. Biasanya komoditi yang dijual ialah kacang tanah dan 
jagung. Singkong hanya dijual bila ada pembeli yang datang dan biasanya langsung ke kebun. Harga singkong dijual pada pedagang dengan harga per kilo hanya berkisar Rp 600 sampai Rp 700. Pada musim panen dan ketika banyak yang menanam singkong, harga jual sekilonya hanya menjadi sekira Rp 300,-. Situasi ini membuat petani enggan menanam singkong dengan serius, karena rendahnya harga jual. Berbeda dengan kacang tanah,yang pada musim panen saja dapat dijual dengan kisaran Rp 6.000 sampai Rp 7.000 perkilo. Metode penanaman masyarakat masih didominasi tumpang sari, jadi dalam suatu hamparan lahan di dalamnya terdapat dua sampai tiga jenis tanaman. Hal itu juga amat bergantung pada kondisi tanah dan luasan tanah yang ditanami. Model ini memang diaplikasi oleh petani sedari dahulu.

Sebagai ilustrasi, untuk wilayah Garut masyarakat yang paling banyak menanam Ubi Kayu secara besar ternyata ada di wilayah Malangbong dengan produksi mencapai 33,149 ton dan dari hasil per hektarnya mencapai 220,55 Kwintal (Dinas Pertanian Kab. Garut). Di Malangbong singkong banyak digunakan sebagai bahan pangan, khususnya dibuat sebagai aci, atau juga biasa dikenal di daerah Jawa Tengah dengan sebutan gaplek. Sementara pati singkong (tepung aci, tepung kanji) disebut sebagai tapioka. Yang disebut gaplek adalah singkong (ketela pohon, ubi kayu/ Manihot esculenta/Manihot utillisima) yang telah dikupas dan dikeringkan. Biasanya singkong dikupas secara manual dengan pisau. Sementara pengeringannya dilakukan dengan cara menjemurnya langsung di bawah panas matahari. Tepung tapioka adalah pati singkong. Pati ini diperoleh melalui penghancuran singkong segar, pelarutan dengan air, pemerasan, pengendapan pati dan pengeringan. Masyarakat tradisional melakukan proses ini secara manual dengan mengupas singkong, memarutnya, memberinya air, memeras lalu mengendapkan air perasan hingga diperoleh pati yang kemudian dijemur sampai kering.

Usaha musiman karena tergantung pada panas matahari tetapi warga tetap tidak meninggalkan usaha pembuatan aci singkong. Sedangkan onggok singkong, merupakan hasil tambahan dalam proses pembuatan aci tersebut. Onggok adalah ampas (limbah padat) dari singkong setelah melalui proses penggilingan dan penyaringan. Singkong dapat dijadikan onggok sebagai makanan ternak masyarakat Desa Cibunar. Jenis atau varietas singkong yang ditanam petani umumnya jenis lokal, dengan umur sekira $4-6$ bulan. Bagi penduduk yang mengandalkan mata pencahariannya sebagai petani, maka singkong ditanam di kebun dekat sawahnya. Namun singkong di sini tidak dikenal sebagi tanaman komersil dan tidak dirawat. Jika digunakan sebagai makanan biasanya diolah menjadi singkong rebus atau goreng, kecimpring yang serupa dengan makanan semacam kerupuk (opak), combro, timus, dan panganan lainnya.

Tabel 1. Luas Panen, Produksi, \& Hasil Per Hektar Tanaman Palawija Kab. Garut Tahun 2008

\begin{tabular}{|c|c|c|c|}
\hline Ubi Kayu & Ha & Ton & Kw \\
\hline Malangbong & 1,503 & 33,149 & 220,55 \\
\hline Cibalong & 1,419 & 31,275 & 220,40 \\
\hline Talogong & 1,370 & 29,954 & 218,64 \\
\hline Cibatu & 565 & 12,44 & 220,30 \\
\hline
\end{tabular}

Sumber: Kab. Garut Tahun 2008

Singkong umumnya dapat ditemui di daerah yang tanahnya tidak produktif dan kurang mendapat air. Di desa Cibunar singkong tersebar tidak merata namun hampir ada di setiap kampung. Meski demikian, luas lahan dan jumlah petani yang menanam singkong di Desa Cibunar tidak tergambar secara jelas. Membuat posisi tanaman ini belum menjadi komoditas yang diperhitungkan secara keekonomian. Singkong memiliki makna sebagai mediator sosial antarmasyarakat setempat. Karena singkong dapat diminta begitu saja seperti orang meminta buah jambu kepada tetangganya.
Asalkan mau mencabut dan pergi ke kebun, akan diberi ijin mengambilnya. Hubungan tersebut juga dijadikan sebagai salah satu sarana untuk bertukar informasi mengenai berbagai hal yang sedang terjadi di desa. pertukaran informasi yang berlangsung saat dikebun sambil mencabut singkong. Melalui obrolan-obrolan di kebun, orang misalnya bisa meminjam uang, menceritakan kondisi keluarganya, mencari dukungan politis, menyebarkan gosip, maupun memamerkan keberhasilan seseorang dalam hal kepemilikan barang baru maupun prestasi. Dengan begitu 
singkong tidak terlampau menyolok dan kuntinyu untuk diperjualbelikan seperti tanaman kacang tanah, kacang kedelai, cabai, atau pun jagung. Kalau pun dijual biasanya oleh pedagang combro yang datang ke kebun, langsung membeli dengan harga Rp 600 sampai Rp 700 per kilo gram.

Singkong yang biasa dikonsumsi di desa ini disebut manehot oleh penduduk lokal. Memiliki tekstur kulit daging berwarna putih dan kalau direbus akan terasa legit dan manis. Penduduk sekitar pun kalau ditanya singkong untuk apa hanya mengatakan "sampe mah didieu saukur kango tuangan, tiasa dianggo mam, umpami aya kalewihanana nembe diical." Meskipun pabrik bioetanol sudah berdiri dan beroperasi namun singkong belum secara luas diketahui dapat menghasilkan energi (etanol). Seperti yang diungkapkan oleh Pak Endi (55 th) di Kampung Pangsor yang sedang menggarap kebun: "Saya tidak tahu, sampeu bisa digunakan jadi bahan bakar.. Emang dari apanya ya bikinnya? Bapak belum dengar kabar itu karena rumah bapak kan jauh dari desa, ga ada informasi tentang itu. Tetapi dulu sempat dengar mau dapet bibit singkong dari pemerintah, ditunggu-tungggu ga dating-datang.,.. Itu juga saya ga paham nanti buat apa bibit singkong itu. Kalo bapa mah singkong ini buat dimakan saja sendiri, karena sedikit juga nanamnya dengan kacang tanah".

Lahan yang ditanami singkong oleh salah satu petani lain memiliki luas sekitar 280 Tumbak dalam satu hamparan. Menyusuri kebun dan melihat kondisi tanam singkong yang ditanam, saat itu tampak dalam kondisi kering. Tanahnya keras dan kering, karena tidak mendapatkan air yang cukup. Umbinya pun ketika dicabut kecil, padahal usianya sudah mencapai 5 bulan lebih. Di lahan seperti itu tanaman apa pun juga membutuhkan perawatan agar umbinya tumbuh dengan baik. Ketika proyek DME berjalan dan pembagian bibit singkong dilakukan, rupanya tidak disertai cara menanam singkong yang baik disertai pola perawatannya. Dalam kondisi tersebut sudah barang tentu umbi tidak akan tumbuh besar. Sebagai tanaman tumpang sari singkong memang tidak menjadi andalan petani sebagai penghasilan pokok, namun hanya sekadar tanaman pendamping (penyelang) saja.

\section{Kepemilikian Lahan}

Sebagian besar lahan masih berada di tangan keturunan pendatang pertama yang menetap lama di Desa Cibunar. Hanya segelintir petani yang memiliki lahan luas, itu pun biasanya ia seorang pedagang kaya atau perantau sukses di kota. Sementara petani yang tidak dapat mengembangkan usahanya selain di pertanian, lahan sawah yang ada dijual untuk kebutuhan lainnya, sehingga petani bekerja sebagai buruh atau penyewa lahan. Perubahan yang ekonomi berlangsung secara umum di luar dan di dalam desa yang semakin terbuka, otomatis menaikan pasaran harga tanah. Hal itu karena berkaitan dengan peningkatan jumlah penduduk di desa, menguatnya daya beli, dan munculnya spekulan tanah dan investor yang membeli tanah setempat.

Kondisi ekologis lahan semakin terdegradasi karena peralihan lahan ke sektor perumahan, pengembangan pabrik, serta peternakan. Pertanian menjadi sektor yang cenderung mengalami kesulitan untuk berkembang mengangkat perekonomian masyarakat desa. Kondisi tersebut memunculkan permasalahan kompleks dengan diferensiasi kepemilikan lahan yang tidak seimbang dan disertai penyebaran berbagai sumber usaha pertanian yang tidak memadai dan proporsional. Berikut ini beberapa sistem penyakapan yang berlaku di Desa Cibunar secara umum:
a. Pemilik tanah (tidak mengarap lahan)
b. Nengah
c. Gacong

Pertama, Untuk pemilik tanah yang memiliki lahan luas di Desa Cibunar atau di luar desa asal. Tanah yang dimiliki mencapai beberapa hektar. Orang ini biasanya tidak terjun langsung bekerja menggarap sawah. Kedua, petani nengah yang sebenarnya memiliki lahan tetapi menggarap atau menyewa lahan orang lain. Upah petani nengah yaitu berasal dari jumlah berat padi kering yang diperoleh ketika panen dibagi dua dengan pemilik lahan. Ketiga, gacong ini adalah buruh tani yang bekerja pada saat musim panen maupun musim tanam yang disebut buburuh gacong. Padi yang telah diarit (ditebas) oleh serombongan laki-laki kemudian diangkatan (dibawa ke pinggir sawah) untuk dirontokkan (ngagebot) dengan papan kayu setinggi pinggang orang dewasa. Semua pekerjaan tersebut dilakukan oleh laki-laki. Sedangkan tugas buruh gacong perempuan adalah mengumpulkan bulir padi yang sudah dirontokkan untuk dipisahkan dari daun dan batang padi yang mungkin ikut dalam bulir-bulir padi.

Setelah proses pemisahan tersebut selesai, buruh gacong perempuan kemudian memasukkan padi-padi ke dalam karung untuk dibawa ke tempat penjemuran padi atau di bawa ke rumah pemilik sawah. Upah untuk buruh cangkul, penjemur padi diupah samapi Rp 25.0000 per hari. Khusus untuk perempuan yang tugasnya tandur (menanam bibit) diupah Rp 20.000,- per hari dengan waktu kerja dari pukul 07.00 - jam 13.00. Petani gurem (nengah) ialah orang yang tidak memiliki lahan atau jika memiliki lahan berkisar 50 tumbak sampai 200 tumbak $\left(1\right.$ Tumbak $\left.=14 \mathrm{M}^{2}\right)$. 
Mereka menggarap sawah untuk memenuhi kebutuhan sehari-hari di rumah. Jika orang yang disebut petani nengah kebanyakan lebih banyak mencari pekerjaan di desa. Mereka dipercaya untuk menggarap tanah kerabat, tetangga, atau temannya. Petani nengah itu biasanya menyetor hasil panen kepada pemilik lahan. Ini presentasinya bisa separuh-separuh, atau sesuai dengan kesepakatan antara yang memiliki lahan denganyang bukan pemilik. Pemilik lahan kebanyakan merupakan tokoh setempat, pebisnis, dan orang yang memiliki usaha di luar desa. Mereka juga sebenarnya merupakan orang-orang yang memiliki modal uang namun, orientasi usaha utamanya berada di sektor non-pertanian. Akses pemilikan tanah atau lahan sawah diperlakukan sebagai bentuk komoditi investasi jangka panjang. Hal itu seperti dilakukan oleh salah seorang Haji kaya dan terpandang di Kampung Cileles yang memiliki tanah atau lahan pertanian yang dibeli di wilayah Cibatu tersebut. Hal itu juga merupakan salah satu cara orang menunjukkan prestise dan mengumpulkan uang atau menyimpan harta kekayannya. Sementara itu golongan yang tidak memiliki modal bekerja di sektor pertanian dan non-pertanian sebagai buruh tani (gacong), buruh bangunan, pedagang kecil-kecilan, tukang ojek, dan jenis pekerjaan yang sifatnya serabutan.

Petani yang terlibat di penanaman singkong relatif berada di kategori petani nengah. Mereka menanam singkong sebagai tanaman pendamping palawija, dengan sistem tanam campuran atau tumpang sari. Singkong tidak dibudidayakan secara serius untuk kebutuhan khusus. Karena pengembangan tanaman tersebut belum menjadi komoditi yang diperdagangkan dalam skala besar di Desa Cibunar maupun di luar desa.

\section{Internalisasi Ide Energi Terbarukan}

Isu energi terbarukan berkembang di Desa Cibunar sekitar tahun 2007, melalui rencana penanaman Jarak Pagar sebagai tanaman energi yang dibawa oleh aktor-aktor dari luar Desa Cibunar. Hal itu kemudian berkembang di beberapa kecamatan yang berada di Garut bagian utara, serta melibatkan masyarakat lokal sebagai penyedia bahan bakunya. Namun wacana tersebut tidak sempat menjadi kenyataan.

Pada tahun 2008 kemudian, muncul gagasan untuk mendirikan desa yang memproduksi energi lokal dan untuk konsumsi masyarakat setempat. Usaha tersebut berjalan karena peraturan Presiden Nomor 5 tahun 2006 mengenai Kebijakan Energi Nasional dan Instruksi Presiden Nomor 1 Tahun 2006 mengenai Penyediaan dan Pemanfaatan Bahan Bakar Nabati atau Biofuel sebagai bahan bakar alternatif yang mulai disosialisasikan ke seluruh daerah di Indonesia. Kebijakan tersebut kemudian diturunkan melalui sebuah program yang salah satu implementasi adalah dengan mengembangkan basis produksi energi alternatif di perdesaaan, praktik ini kemudian dinamanakan Desa Mandiri Energi (DME). Fokus pelaksanaan DME adalah pada daerah atau desa yang sulit aksesibilitasnya, kekurangan sumberdayanya, dan sulit pekerjaan.

Misi yang didorong melalui DME ialah program pengentasan kemiskinan masyarakat perdesaan dengan menyediakan dan membuka lapangan pekerjaan. Kemudian membuat masyarakat mandiri secara energi agar tidak tergantung terhadap bahan bakar fosil. Bahan bakar fosil yang banyak di konsumsi oleh masyarakat saat ini bukan saja tidak dapat diperbarui namun juga akan habis dalam jangka waktu tertentu. Untuk itu kesiapan desa diharapkan oleh pemerintah dari sisi lahan, sumber daya alam, dan manusianya menjadi tulang punggung pengembangan energi alternatif berbahan baku nabati.

Berikut secara deskriptif akan diuraikan proses masuk perkembangan dan kelanjutan implementasi produksi energi alternatif. Pada awalnya ternyata rencana ini berasal dari inisiatif segelintir orang.

Di Desa Cibunar sendiri isu energi alternatif masuk melalui Pak Ujang. Ia adalah seorang pensiunan dari P.T Indocement di Divisi Instrumentalis yang berasal dari Kampung Parakan Telu di Desa Cibunar dan saat ini bermukim di Bogor. Ide menanam Jarak Pagar itu berawal dari perkawanan dan informasi dari Pak Dudi yang bekerja di PT. Indotrans, pada tahun 2007. Pak Dudi berencana mengadakan kerja sama dengan Perusahaan dari Austria yang ingin membeli Jarak Pagar. Pada prosesnya, setelah mengumpulkan semua data yang dilakukan oleh Pak Dudi dan Pak Ujang, pihak perusahaan Austria hanya mau membeli produk minyak jarak saja, bukan buahnya. Karena kurang siapnya infrastruktur mesin dan ketidaksiapan lahan dan keterbatasan modal, maka kerjasama antara pihakpihak lokal dan perusahaan Austria tersebut menemui titik buntu dan terhenti tanpa ada kelanjutannya.

Seiring berjalannya waktu, bersama Pak Edi Kusnadi, Pak Ujang kemudian mengagas pertanian padi organik dengan menggunakan pupuk kompos. Di tahun 2003, melalui kelompok padi organik yang menaunginya kegiatan kelompok tani padi organik sudah melatih masyarakat di tingkat RW untuk memanfaatkan limbah rumah tangga menjadi kompos. Pada waktu itu juga mereka mulai mengiatkan pertanian organik dengan metode SRI (System Rice Intensification) yang ramah tingkungan dan irit air. 
Latar belakang Pak Edi ialah sebagai seorang Pegawai Negeri Sipil di Dinas SDAP dan aktif sebagai ketua BPD (Badan Permusyawaratan Desa) di Desa Cibunar. Ia juga merupakan teman sejawat Pak Yoyo yang menangani masalah energi di Dinas SDAP Kabupaten Garut. Kelompok yang kemudian nanti dinahkodai Pak Edi tersebut, sebelum inisiasi program pembuatan bioetanol tidak mengetahui apa bahan bakar nabati tersebut. Pasca dipilihnya Desa Cibunar dengan mendapatkan bantuan untuk pengembangan pabrik bioetanol yang didorong oleh Kementerian ESDM, mereka semakin mengenal wacana energi terbarukan yang berbasis pada bahan baku singkong. Pihak penghubung dari pemerintahan Desa Cibunar untuk mengiring program tersebut atas dasar usaha dan inisiatif Pak Edi. Pada waktu itu juga ia merupakan anak buah sekaligus teman Pak Entang yang bertugas sebagai Kepala Divisi Keenergian di Dinas SDAP. Melalui jejaring tersebut, Pak Edi meminta agar proyek pendirian pabrik bioetanol diusulkan ke Desa Cibunar untuk kemudian dikelola olehnya.

Pak Edi bersama Kepala Desa Cibunar pada waktu itu menyatakan kesiapan lahan untuk demo plot (demplot) lahan seluas 10 Hektar di wilayah Desa Cibunar. Mereka berdua menjamin bahwa masyarakat sudah tidak asing dengan tanaman singkong dan paham untuk membudidayakannya. Setelah kesepakatan tersebut, disiapkanlah rapat untuk memasuki proses administrasi guna pengguliran bantuan program DME dari Kementerian ESDM tersebut kepada Dinas SDAP Kabupaten Garut dan Bupati Garut. Pengembangan DME berbasis singkong, hanya melibatkan kementerian dan dinas terkait saja sebagai pelaksana program serta beberapa perangkat desa.

Pada proses puncaknya, hasil interaksi antara Pak Edi dan Dinas SDAP Kabupaten Garut menghasilkan pengajuan rekomendasi kepada Kementrian ESDM untuk membangun DME di Desa Cibunar dengan dikelola langsung oleh Pak Edi. Hanya diperlukan proses selama tiga bulan dari tanda tangan (MOU) antara kementerian dan pemerintah daerah, yang akhirnya pabrik resmi berdiri bulan Oktober 2009. Berdasarkan dari hasil uji coba mesin tersebut diketahui bahwa kemampuan mesin dalam memproduksi bioetanol jauh di bawah dari apa yang disampaikan oleh pemerintah yang diwakili oleh konsultan dan pembuat mesin. Mesin bioetanol, dengan kapasitas 400 liter per hari setelah diuji coba hanya menghasilkan 150 liter per hari. Proses tersebut dilakukan selama hampir 24 jam, namun dengan proses hanya menghasilkan sekira 50\% sampai $70 \%$ kadar alkohol. Tetapi untuk menghasilkan kadar $90 \%$ ke atas, paling hanya menghasilkan etanol dibawah 100 liter per hari, jauh dari kenyataanya.

Gambar 1. Bangunan Pabrik Bioetanol dan Akses Jalan

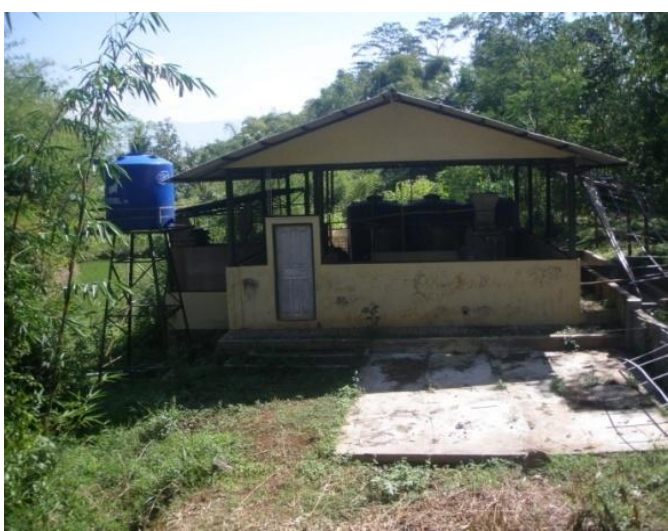

Karakter pengenalan program bioetanol berbasis singkong diawali tanpa partisipasi oleh seluruh lapisan masyarakat desa. Program yang hanya direncanakan Kementerian ESDM tersebut membawa implikasi keberlanjutan terhadap program yang diusungnya. Program tersebut hanya didelegasikan melalui Pak Edi yang kemudian dibantu beberapa orang saja tanpa ada internalisasi dan sosialisasi yang cukup.

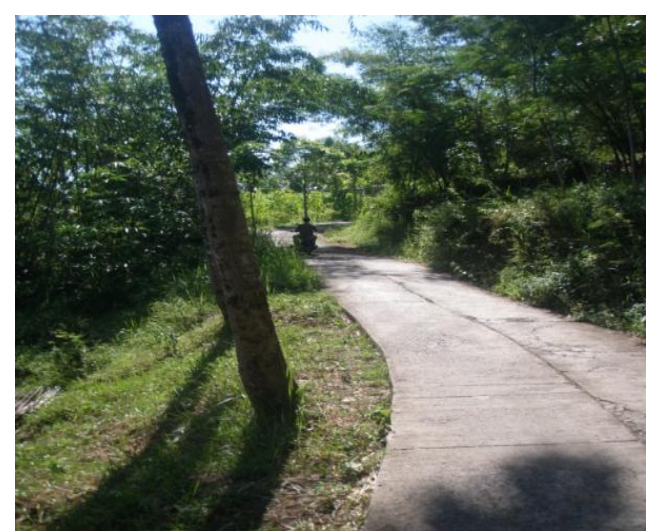

\section{Praktik Energi Alternatif dan Masyarakat}

Pembentukan Kelompok Usaha Petani Produktif (KUPP) di Desa Cibunar bukan sebuah kelompok yang terbentuk dari kesolidan petani lokal. Namun kelompok yang "tiba-tiba berdiri" ketika program bioetanol masuk ke desa. Pengelola yang membentuk kelompok seolah berasal dari tingkat lokal, padahal hanya melibatkan partisipasi yang terdiri dari beberapa 
orang, yaitu Pak Edi, Pak Ujang, dan Pak Asep (merupakan anggota BPD sekaligus kerabat dari Kades Cibunar). Selain pertemanan, hubungan sosial yang bertolak dari hubungan pribadi yang penting di perdesaan adalah hubungan patronklien. Patron-klien adalah hubungan yang melibatkan seseorang atau beberapa orang yang memiliki sumber-sumber kesejahteraan di satu pihak (patron), dengan orang-orang yang membutuhkan sumber-sumber tersebut di pihak lain (client). Di antara kedua pihak itu terjadi ikatan yang bersifat saling memberi dan menerima (Boissevain,1969 dikutip Irianto,1993:246). Menurut Wolf, hubungan patronklien adalah bentuk hubungan pertemanan instrumental. Pertemanan bentuk ini, meskipun terjadi secara tidak seimbang, karena salah satu pihak lebih berkuasa daripada pihak lainnya dalam kapasitasnya untuk memberikan energi atau sumberdaya, namun, bagi klien dan juga kadang sang patron, hubungan ini dipandang sebagai jaminan sosial yang menyediakan bantuan-bantuan tertentu yang dibutuhkan pada saat-saat tertentu (Wolf, 1978:17-8).

Kelompok-kelompok tani (per wilayah kampung) yang ada di Desa Cibunar, tidak dilibatkan secara kelembagaan di dalam pelaksanaan penyediaan singkong untuk pabrik. Dengan berdirinya pabrik etanol maka Pak Edi membentuk KUPP Desa Cibunar. Ada pun orang yang dilibatkan sifatnya hanya individu dari beberapa ketua kelompok saja. Namun, tidak di dalam kesatuan kelompok dan antarsesama kelompok tani. Petani dikumpulkan di desa kemudian hanya dibagikan bibit singkong bantuan dari pemerintah.
Proses sosialisasi di balai desa dilakukan bersamaan dengan pembagian bibit singkong. Bagi petani yang punya punya lahan kosong pada waktu itu dihimbau terlibat menanam singkong tersebut. Pembagian bibit pun dilakukan melalui perwakilan ketua RW atau ketua kelompok-kelompok tani yang hadir ketika acara itu berlangsung. Pembagian bibit kemudian tersebut diteruskan kepada petani yang menanamnya di masingmasing wilayah atau kelompok tani.

Pengakuan beberapa kelompok tani mengindikasikan bahwa pembagian tersebut tidak merata dan dengan ketidakjelasan mekanismenya. Bibit singkong tersebut dibagikan-bagikan begitu saja ke masyarakat yang berminat menanamnya. Namun, ada petani yang menerima dan ada juga yang menolaknya. Petani yang terdata sebelumnya untuk menanam, justeru tidak mendapatkan bibit singkong tersebut. Untuk biaya tanam dan pupuk yang sebenarnya telah dianggarkan oleh Kementerian ESDM, namun tidak jelas dibagikan kepada siapa saja.

Pada masa pasca tanam pun tersebar kabar bahwa singkong untuk BBN itu ialah singkong racun. Jadi kalau dikonsumsi manusia dapat menyebabkan keracunan. Hal itu salah satu yang menyebabkan petani enggan menanamnya. Belum selesainya persoalan ketersediaan bahan baku dan kualitas singkong, datang bantuan paket kompor etanol. Kompor tersebut diharapkan digunakan untuk masyarakat sebagai alternatif untuk memasak di rumah. Pengadaan kompor tersebut dilakukan oleh Kementerian ESDM dengan melibatkan perusahaan kompor yang dikelola oleh Dikdik Sudarmanto yang berkedudukan di Surabaya.

Gambar 2. Kompor Bioetanol

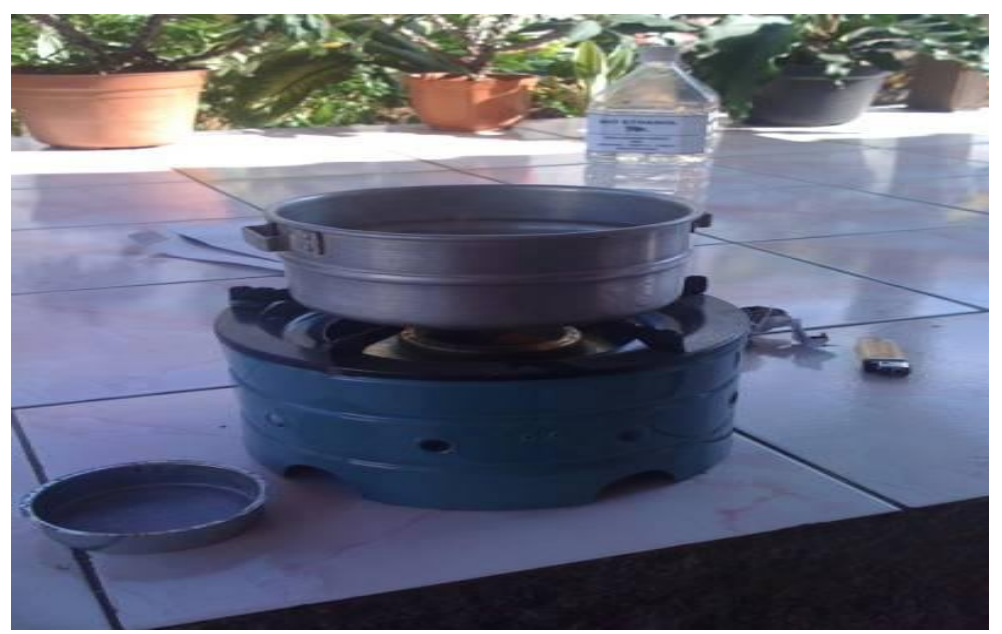

Sumber: Dokumen Pribadi 
Paket bantuan kompor etanol dari Kementrian ESDM dialokasikan sebanyak 300 unit, padahal jumlah KK dalam satu desa pada waktu itu mencapai $3.000 \mathrm{KK}$ lebih. Jadi mekanisme pembagian kompor pun diserahkan kepada ketua-ketua RW (14 RW) yang menyatakan hanya menerima kompor masingmasing sebanyak 10 unit. Memang mekanisme pembagian kompor dari pengelola pabrik dan perangkat desa seperti tidak jelas sasarannya untuk siapa dan rumah tangga yang bagaimana. Kalau pun dihitung jika masing-masing RW hanya kebagian 10 kompor, maka total kompor untuk warga hanya separuhnya (140 unit), lantas sisa kompor itu tidak diketahui untuk apa. Di beberapa kampung pun ada yang hanya mendapatkan kompornya saja, namun tidak dengan bioetanolnya.

Ketika peneliti memilih beberapa kampung dan tersebar di seputr wilayah Desa Cibunar, ada juga yang tidak mengetahui apa itu bioetanol. Penduduk yang berada jauh aksesnya dari jalan masih relatif banyak yang menggunakan bahan bakar kayu sebagai untuk memasak yang didapatkan di dekat lingkungsn sekitar. Masyarakat mendapatkan kayu bakar dengan mencarinya ke kebun yang ada di dekat rumah, di sepanjang sungai Cimanuk, atau kayu kaso bekas membangun rumah yang sengaja dikumpulkan.

Secara umum, sebetulnya di dalam kehidupan masyarakat desa sehari-hari tidak tampak adanya persoalan kesulitan untuk akses energi sehari-hari. Untuk bahan bakar rumah tangga di beberapa RW masih relatif banyak yang menggunakan kayu bakar (kompor hawu). Sedangkan untuk bahan bakar kendaraan bermotor banyak kios yang menawarkan bensin premium eceran dengan harga Rp 5.000 - 6000 per liternya. Penggunaan gas elpiji $3 \mathrm{Kg}$ juga ditemui di rumah yang letaknya jauh dari desa, namun dangan kondisi rumah yang sudah permanen. Secara umum, kebanyakan rumah menggunakan keduanya-kompor hawu dan kompor gas $3 \mathrm{Kg}$ - untuk memasak di rumah.

Selama konversi gas, pasokan bahan bakar untuk memasak itu tidak mengalami hambatan. Gas elpiji banyak dijual di toko atau warung kelontong di seputar wilayah Desa Cibunar. Kesulitan gas elpiji $3 \mathrm{Kg}$ hanya dirasakan terjadi jika hari libur panjang atau hari raya lebaran. Kalau pun ada, harga elpiji itu menjadi mahal karena kemungkinan pasokan dari P.T Pertamina terhenti sejenak. Namun tentu masalah akan muncul jika harga gas $3 \mathrm{Kg}$ itu berpotensi naik harganya dan kelaangkaan akan terjadi. Jika demikian yang terjadi maka kompor hawu yang menggunakan kayu bakar menjadi andalan.

Penggunaan kayu bakar yang menggandalkan pencarian di sepanjang Sungai Cimanuk umumnya dilakuka ketika orang pulang bekerja dari kebun atau sawah. Kayu dari batang pohon dan kayu bangunan ini tidak didapatkan setiap hari, namun dikumpulkan di belakang rumah atau dapur. Di masyarakat desa kayu untuk pemakaian memasak tersebut tidak spesifik harus kayu dari satu jenis, namun dari kayu apapun asalkan dapat dibakar. Sayangnya belum terdapat konsep di tengah masyarakat ketika ia mendapatkan kayu, maka harus merawat atau menanam pepohonan yang dapat menghasilkan kayu bakar tersebut.

\section{Gambar 3. Tumpukan Kayu Bakar Di Belakang Rumah}

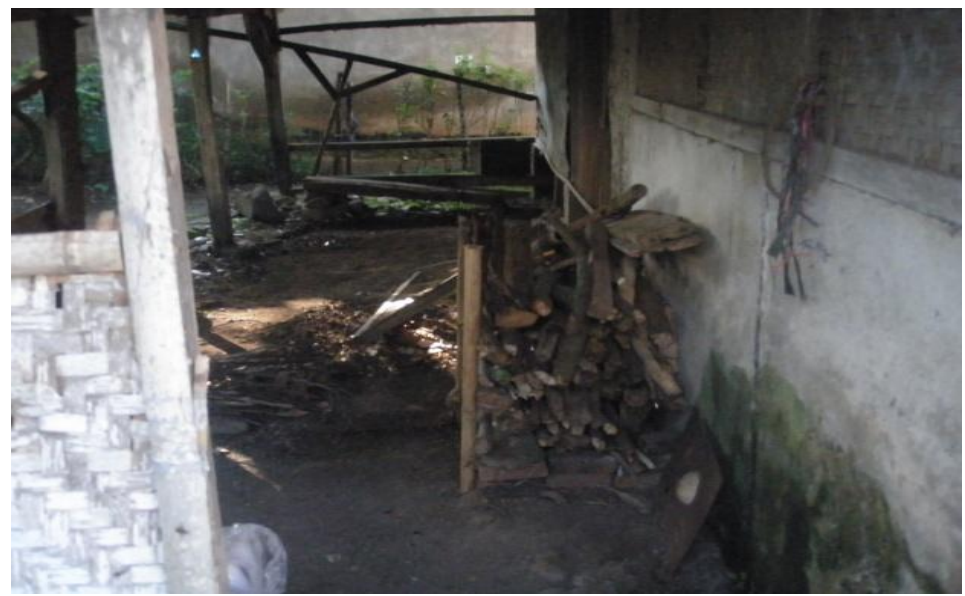

Sumber: Dokumen Pribadi 
Program pengembangan bioetanol di desa muncul tahun 2009 bersamaan dengan konversi gas. Jadi penentuan antara program gas elpiji dan bioetanol sebagai bahan bakar memasak muncul secara bersamaan. Konversi gas lebih muncul diawal ketimbang penggunaan bahan bakar bioetanol. Karena program konversi gas, sudah berlangsung sekira dua tahunan, maka komparasi keunggulan dilakukan oleh pengguna kompor elpiji $3 \mathrm{Kg}$ dengan kompor etanol. Kompor etanol dianggap terlalu kecil, tidak bisa masak yang banyak dan besar. Kendala teknis kompor pun juga masih kerap terjadi. Masyarakat yang menggunakan kompor bioetanol mengungkapkan, kompor itu tidak dapat dipakai memasak makanan dalam jumlah besar dan pemanasannya dirasakan lama. Tidak ada tombol pengatur api sehingga tidak praktis penggunaanya karena daya tampung minyak yang sedikit. Untuk perbandingan menurut orang yang menggunakannya hanya bisa memasak imie, masak telor, dan air saja.

Masalah di atas ditambah dengan situasi harga jual etanol ke masyarakat_-Rp 8.000 - yang dirasakan mahal dibandingkan dengan harga gas elpiji ukuran $3 \mathrm{Kg}$. Meski begitu, harga Rp 8.000,tersebut menurut KUPP belum sesuai dengan ongkos produksi yang berkisar per lier mencapai Rp 10.000 - Rp 13.000 per liter etanol. Karena saat itu sifatnya masih uji coba selama masa produksi, penjualan yang jauh dibawah harga produksi tetep dilakukan. Lambat laun ongkos produksi menjadi tinggi, pabrik tidak berproduksi akibat dari kurangnya modal dan hambatan teknologi. Fluktuasi harga singkong juga terjadi untuk keperluan bahan baku pembuatan etanol. Karena harga singkong mentah semakin mahal karena beban ongkos mengantar dari kebun singkong ke pabrik. Di tambah lagi belum ditemukan jenis singkong yang dapat menghasilkan pati tinggi untuk meningkatkan kadar alkohol etanol. Kendala teknis tersebut ditenggarai oleh pengelola pabrik sebagai penyebab utama timbulnya kemandegan program bioetanol tersebut.

Proses pengenalan singkong menjadi etanol tidak sepenuhnya menyebar dan diketahui oleh seluruh penduduk desa. Karena proses pengenalan program yang sangat cepat membuat masyarakat tidak paham. Informasi yang disebarkan oleh KUPP hanya di lakukan di balai desa melalui ketua kelompok tani dan RW saja, tidak kepada seluruh masyarakat desa. Itu pun berlangsung hanya satu hari, sekaligus dengan pembagian bibit singkong. Pengurus inti kebanyakan juga pemilik lahan sedangkan petani tanpa lahan (penggarap) tidak pernah diajak untuk berdiskusi dan terlibat. Petani pemilik yang menerima bantuan bibit singkong enggan menjual hasil panennya karena harga jual ke pabrik tidak cocok. Begitu pun juga petani penggarap yang menanam singkong tidak serta merta menjual singkongnya ke pabrik bioetanol karena pertimbangan harga dan kurangnya informasi. Petani membutuhkan biaya transportasi dan tenaga untuk mencabut singkong di kebun, namun dibeli oleh pengelola pabrik dengan harga yang dianggap murah saat itu. Pengelola pabrik bioetanol pun ketika itu hanya mau membeli singkong warga yang diantar langsung ke pabrik.

Petani Di Desa Cibunar secara umum tidak mengetahui bibit singkong khusus yang memiliki buah dan kadar patinya tinggi. Namun jika bibit ingin bagus dan dapat menghasilkan buah yang besar, harus mencapai usia delapan bulan atau lebih. Kemudian tidak hanya sekadar ditanam saja, namun tanah digali atau dilubangi agar umbinya dapat tumbuh baik. Pemberian pupuk kompos dan air yang cukup juga menjadi perhatian. Jadi kurang tepat jika ada pernyataan singkong adalah tanaman yang tidak membutuhkan perawatan. Jika singkong tersebut dalam konteks tanaman budi daya sudah barang tentu perawatan musti dilakukan dari aspek bibit, tanah, air, pupuk, dan pola tanam. Karena di wilaya ini singkong hanya dipandang sebagai tanaman tumpang sari saja, maka perlakuannya masih dianggap sebagai tanaman pelengkap di kebun.

Petani yang sempat menanam dan panen singkong, kesulitan menjual singkong ke pabrik etanol karena pada waktu itu pabrik hanya mau menerima singkong di tempat per kilogram Rp $800,-$. Jika petani menjual singkongnya ke pasar atau ke pembeli langsung harga singkong mencapai Rp1.000,- lebih. Hal itu yang kemudian membuat petani "enggan" menjual hasil panen singkong ke pabrik bioetanol karena singkong dibeli murah. Faktor itu yang kemudian sebaliknya menyebabkan pabrik tidak maksimal menyerap bahan baku dari petani, karena ketidakcocokan harga. Pengelola pabrik bioetanol mengakui bahwa untuk membeli harga singkong di petani tersebut mengalami kesulitan kesepakatan harga. Petani menginginkan singkong dibeli dengan harga tinggi, karena melihat pembuatan bioetanol merupakan proyek pemerintah, jadi dianggap terdapat banyak pendanaan. Karena harga singkong di petani Desa Cibunar naik, maka sebagian bahan baku dibeli dari luar wilayah Desa Cibunar. Pengelola juga memerlukan singkong yang sudah dikupas, namun petani setempat tidak mau sampai mengupasnya. Untuk itu pengelola pabrik juga mengeluarkan biaya kupas singkong per kilo gram $\mathrm{Rp} 50,-$. Hal itu dilakukan oleh KUPP dengan melibatkan ibu-ibu rumah tangga yang tidak memiliki kegiatan untuk mengupas singkong. Di situ terlihat antara petani dan pengelola pabrik etanol belum membentuk 
mekanisme kerjasama yang saling menguntungkan satu sama lain.

Mekanisme pengaturan dan kesepakatan harga serta kelangsungan suplai singkong ke pabrik tidak dapat dipastikan. Kepranataan secara sosial dan ekonomi dalam konteks budidaya singkong tidak terjadi di dalam kelompokkelompok petani setempat. Ada kecenderungan petani bersikap pragmatis dengan melihat program pengembangan bioetanol berbasis singkong sekadar tempat mendapat keuntungan secara ekonomi namun yang terjadi justeru sebaliknya.

\section{Strategi Pengelola Bioetanol Berjalan Sendiri}

Sejak awal program energi terbarukan ini diinisiasi oleh pemerintah ke masyarakat di perdesaan (bersifat top-down), yang melibatkan beberapa tokoh masyarkat desa saja. Pelibatan masyarakat secara intens tidak dilakukan sedari awal dalam konteks luas dan kewilayahan. Ketika program itu terhambat dan berhenti, masyarakat pun tidak terlalu peduli. Hal itu memperlihatkan bahwa praktik pembuatan bioetanol, belum bermakna bagi masyarakat sekitar.

Akibat situasi tersebut, strategi yang dilakukan KUPP dalam jangka pendek dan parsial ditujukan dengan usaha dan upaya yang sifatnya parsial dan individual untuk sekadar memperoleh bantuan guna menggerakkan pabrik kembali. Tidak adanya kemampuan sumberdaya manusia, daya dukung mesin, bahan baku, dan dukungan finansial menjadi alasan utama sulitnya pendanaan secara swadaya. Ikatan masyarakat dan pranata yang longgar ketika kebijakan ini di dorong ke desa juga menimbulkan dampak apatisme di kalangan masyarakat terhadap program tersebut. Hal itu merupakan implikasi bahwa program pengembangan bioetanol tersebut tidak dilakukan dengan perencanaan yang baik dari mulai penanaman bahan baku sampai kepada produk akhirnya.

Kondisi lahan yang ada pun memiliki kendala yang besar, karena kondisi lingkungan yang kering dan konturnya yang berbukit menyulitkan menanam singkong dengan menghasilkan kualitas yang baik. Karena kendala itu tidak teramati dari awal oleh pemerintah, maka upaya yang dilakukan untuk menggerakan kembali pabrik etanol tidak dianggap sebagai usaha bersama yang patut diperjuangkan. Artinya, petani hanya dilibatkan sebatas menanam singkong saja, tidak dilibatkan dari awal sebelum program bergulir. Karena itu petani sekitar bersikap biasa saja ketika pabrik tidak lagi sanggup berproduksi. Kenyataanya memang tidak melibatkan petani secara erat dan berkesinambungan. Hal itu akhirnya menunjukkan bahwa belum ada keterikatan secara emosionil antara masyarakat (khususnya petani) dengan pemerintah yang apakah betul memikirkan persoalan masyarakat di desa, atau hanya fokus kepada keberlangsungan pabrik etanol saja.

Tutupnya pabrik tidak memengaruhi petani atau kondisi pasar singkong. Karena kehadiran pabrik etanol pun belum dirasakan manfaatnya terhadap petani, seperti pengaruh terhadap perubahan pada pola tanam, harga singkong, dan perlakuan terhadap tanaman singkong. Singkong masih diperlakukan sebagai tanaman tumpang sari, belum menjadi komoditi yang dapat dijual secara masal. Pasca tutupnya pabrik, petani yang punya lahan kebun (tanah darat) tidak mengubah mekanisme tanam dan perlakuan terhadap singkong. Masih ada petani yang menanam singkong namun hanya untuk keperluan tanaman penyelang (pelengkap) jika terjadi puso (gagal panen padi). Seperti digunakan untuk keperluan sehari-hari untuk membuat panganan kecimpring atau peuyeum. Tidak adanya kepentingan bersama yang selaras dan hubungan emosional itu membuat pabrik bioetanol tidak diperjuangkan untuk beroperasi kembali secara bersama.

Kondisi pabrik yang dilepas kontrolnya begitu saja oleh Kementerian ESDM kepada pihak desa di dalam pelaksanaanya membuat pabrik tersebut tidak berkembang. Padahal pemerintah sepatutnya banyak membantu dari segi transfer pengetahuan, pembentukkan pranata lokal, masalah pendanaan, dan persoalan teknis lainnya. Terhentinya pabrik begitu saja tanpa ada perhatian, merupakan implikasi dari inkonsistenan inisiasi awal dari Kementerian ESDM dan Pemerintah Daerah yang tidak mendamping dan membantu dari segi finansial, peralatan yang memadai, serta kemampuan kapasitas orang dalam mengelola mesin di pabrik sampai pabrik dapat berjalan.

Berdasarkan situasi dan kondisi tersebut, pilihan strategi KUPP yang didominasi Pak Edi secara pribadi memilih berpartisipasi dalam pameran, stand, atau expo yang diadakan di tingkat kabupaten atau Provinsi di Jawa Barat. KUPP kerap mengikuti ajang tersebut dengan menampilkan varian usaha yang dikembangkan antara lain, yaitu komoditi padi organik dengan metode SRI dan penggunaan pupuk kompos. Lalu, produk bioetanol pun disertakan di dalam setiap kegiatan pameran yang diikuti. Melalui ajang itu KUPP berusaha membangun dukungan keluar dengan "meminta bantuan" melalui jaringan yang mereka miliki.

Untuk strategi yang saat ini yang dilakukan lebih berupaya untuk bertahan dan melihat peluang bantuan. Saat ini KUPP tidak hanya menghasilkan bioetanol namun juga membuat tepung mokaf berbahan baku singkong. Tepung mokaf yaitu tepung berasal dari singkong yang pembuatannya digiling dan kemudian dikeringkan. Tepung 
tersebut merupakan pengganti tepung terigu yang disinyalir tidak memiliki senyawa gluten. Pak Edi menggolah mokaf di KUPP setelah bergelut dengan pembuatan etanol dan mengetahui dari kelompok-kelompok pertanian yang ada di Kabupaten.

Beberapa pelaku etanol di dalam KUPP optimis singkong dapat menjadi bahan baku energi alternatif dan menunjang perekonomian desa. Ditambah lagi ada perkembangan bahwa akan dibangun kembali pasar daerah dan terminal di wilayah Kampung Parakan Telu di Desa Cibunar. Sudah barang tentu beberapa orang (di KUPP) memiliki kepentingan dan keinginan agar pabrik berjalan kembali. Namun, kepentingan KUPP terhadap arah pengembangan bahan bakar nabati memiliki kecenderungan, sebagai berikut:

1. Terlibat aktif dengan pemerintahan di kabupaten dengan menyuarakan bahwa pabrik etanol telah ada dan menghasilkan. Untuk itu aktor kunci KUPP, menyatakan bahwa gerakan ini musti didukung dan berjalan terus. Namun dukungan yang dimaksud bukan mengarah upaya gerakan budaya, penguatan kepranataan petani lokal, dan mengakomodasi kepentingan semua lapisan masyarakat desa (aspek sosial), namun lebih ke pendanaan, lahan singkong, dan kendala teknologi (aspek teknis).

2. KUPP mengembangkan varian singkong menjadi tepung mokaf yang berasal sebagai pengganti atau pelengkap tepung terigu yang merupakan produk andalan pangan yang dipopulerkan dalam seminar atau pameran daerah-selain pupuk kompos dan beras organik.

3. Pak Edi dan Pak Ujang mengusulkan kepada pihak yang memiliki otoritas (Kementerian ESDM) agar terjadi serah terima pabrik dan alatnya dari Kementerian ESDM ke Bupati Garut, lalu secara legal ke Kantor Desa Cibunar. Merurut mereka (pihak KUPP), jika tidak diserahterimakan maka akan sulit untuk mengajak pihak swasta investasi di pabrik bioetanol tersebut. Jadi bantuan pendanaan juga dapat berasal dari luar unsur pemerintahan dengan menggunakan sistem bagi hasil atau sistem sewa.

Adapun strategi lain yang dilakukan oleh Pak Edi untuk menghidupkan dukungan terhadap pabrik bioetanol yaitu dengan aktif di beberapa organisasi masyarakat. Salah satunya keterlibatan Pak Edi sebagai pengurus Paguyuban Petani Pengembang SRI (P3-System Rice Intencification) Kababupaten Garut (sebagai Sekretaris I) dan sebagai salah satu anggota Masyarakat Singkong Indonesia (MSI) di Kabupaten Garut. Keaktifannya tersebut merupakan salah satu strategi memperluas jejaring relasi untuk memperkuat apa yang telah dilakukannya saat ini. Sebab usaha yang dilakukan olehnya masih berhubungan erat di ranah pertanian. Paguyuban Petani SRI merupakan organisasi yang bergerak untuk memasyarakatkan pertanian berbasis pada alam dengan tidak menggunakan pola tanam konvensional, pemupukan kimia, dan pemeliharaan yang anti terhadap penggunaaan bahan kimia. Aktifitas yang Pak Edi lakukan di MSI terjadi sekira akhir tahun 2010, dengan misi pemberdayaan masyarakat melalui revitalisasi produksi singkong agar memiliki keunggulan dan daya tawar yang lebih baik dengan cara diolah lebih lanjut. Melalui keaktifannya diorganisasi tersebut Pak Edi dibantu modal untuk pengembangan tepung mokaf dan saat ini sedang dilakukan proses pemberian mesin penggiling singkong sebagai salah satu alat pembuatan tepung.

Pergesaran pengembangan tersebut terjadi karena Pak Edi dan KUPP belum melihat pabrik etanol akan segera dihidupkan kembali oleh pemerintah. Maka ia memilih jalan dengan memanfaatkan singkong sebagai varian pangan lainnya. Ia mengatakan bahwa masih berminat mengembangkan singkong untuk etanol, hanya saja butuh modal lagi dari pemerintah atau investor dari luar. Orientasi jejaring yang dipilihnya masih keluar desa, tidak memperkuat kelembagaan di level petani yang nota bene berhubungan erat dengan apa yang dilakukan olehnya saat ini.

KUPP kerap kali mengemukakan problem utama keberlanjutan pabrik harus diselesaikan dengan cara mendatangkan investor atau bantuan kembali dari pemerintah. Pada kenyataanya kajian beberapa data menunjukkan bahwa bantuan itu bukanlah letak persoalan utama. Hal yang dibutuhkan ialah upaya untuk mendorong interaksi antarsesama warga desa dan hubungan dialogis ketika sebelum dan setelah program berlangsung. Upaya itu tentu di dalam suasana semangat mengembangkan energi alternatif dalam konteks lokal. Hal itu dilakukan agar dukungan praktik energi alternatif singkong dapat diketahui dan dipahami dam kondisi kebatinan dan kebersamaan. Itu hal utama yang semustinya dibangun dalam usaha memupuk rasa kebersamaan dan gerak kemajuan masyarakat di desa tersebut.

\section{KESIMPULAN}

Persoalan pemenuhan energi menjadi persoalan bangsa, namun membutuhkan strategi dan tepat ketika diimplementasikan. Terlebih lagi yang menjadi program sasaran ialah masyarakat di 
pedesaan. Kebijakan energi alternatif melalui program pengembangan bioetanol hanya merupakan satu dari sekian banyak program untuk masyarakat desa. Program yang berusaha untuk mengatasi persoalan di perdesaan dengan dalih membebaskan masyarakat desa dari ketergantungan dan kemiskinan. Padahal orientasi dan tujuan yang terlihat hanya sekedar mewujudkan program saja, bukan membuat strategi untuk membangun masyarakat desa secara tertata dan terintegrasi.

Hasil pembelajaran yang diperoleh secara umum terdapat tiga permasalahan yang menyebabkan program tersebut terhenti yaitu: pertama, masalah hubungan sosial di masyarakat (petani) yang longgar karena program tidak partisipatif serta ketiadaan kelembagaan yang kuat dan menganggap program tersebut sama seperti program-program sebelumnya dari pemerintah. Kedua, sektor pertanian dianggap kurang menarik karena hasil yang didapatkan rendah dan resiko gagalnya besar sehingga banyak orang yang memilih bekerja ke luar desa. Lalu ketiga, persoalan lahan yang kering karena tidak tersedianya air di dalam jaringan irigasi yang baik untuk lahan-lahan yang tersebar di desa.

Karena ekspektasi masyarakat di desa tidak tergali dengan baik sebelum program diterapkan. Maka persoalan energi terbarukan berbasis tanaman nabati tidak terlampau dihiraukan oleh warga masyarakat, khususnya petani. Akibatnya isu bioetanol sebagai bahan bakar tidak memiliki makna karena memang tidak menyentuh persoalan masyarakat desa. Aspirasi mengemuka ialah ekspektasi dalam mengatasi persoalan pertanian ketimbang membuat pabrik bioetanol. Penyelesaian persoalan di sektor pertanian dianggap krusial karena kondisi lahan yang semakin kritis dan mengalami degradasi karena penggunaan bahan kima selama puluhan tahun dan kendala kesulitan air yang belum terselesaikan.

Kondisi kekeringan di Desa Cibunar itu terjadi sejak masifnya ledakan penduduk dan terjadi degradasi lingkungan yang menyebabkan menurunnya kualitas produktifitas alam yang terkait dengan kualitas tanah, dan air. Persoalan tersebut memunculkan pengenalan program Padi System Rice Intensification (SRI) yang dibawa oleh Kementerian Pertanian dengan tujuan ingin mengembalikan pertanian dengan cara tradisional dan alami. Metode tersebut mengaplikasi bentuk pola tanam, sistem pengairan yang sedikit, pemupukan, dan penggunaan bibit yang berbeda dengan pertanian konvensional.

Untuk tidak menutup ruang bagi terbukanya kemungkinan pengembangan energi alternatif di pedesaan, maka pertama perlu diadakan revitalisasi di sektor pertanian. Hal itu dilakukan untuk menggerakan kembali perekonomian di perdesaan. Basis ekonomi pedesaan mau tidak mau memang harus diletakkan dalam kerangka untuk mendukung kemajuan pertanian. Sehingga integrasi program-program yang dilakukan memang mesti mengacu kepada model pertanian yang nantinya sudah terbentuk, sehingga tidak membuat perubahan konstelasi pertanian yang semakin memperparah kondisi bahwa sektor tersebut tidak menarik bagi generasi saat ini.

Melihat dari pola pendekatan dan implementasi yang masih bersifat top down dan proyek semata yang sudah tentu tidak berkelanjutan. Persoalan mendasar masyarakat di desa yang terkait dengan lahan dan pertanian saja tidak diselesaikan terlebih dahulu. Pemerintah lebih mendorong implementasi kebijakan energi alternatif berbasis singkong, akibat desakan lonjakan harga minyak bumi dunia. Tanpa roadmap, perencanaan yang matang, partisipatif dan inklusif tentu akan berimplikasi pada mandeknya program tersebut. Hal itu terlihat di dalam implementasi program energi terbarukan berbasis tanaman, namun yang mengemukan malah persoalan tata kelola lahan, budaya masyarakat setempat, dan aspek sosial dan kebutuhan yang luput dari target yang hendak dicapai.

Problem mengemuka bukan pada fleksibilitas dan keberlanjutan energi tersebut, namun yang mendesak bagi masyarakat desa yaitu kebutuhan air dan irigasi pertanian. Aspirasi dan ekspektasi yang muncul di masyarakat khususnya di kalangan petani terfokus pada pemecahan masalah ketersediaan air untuk kebutuhan pertanian ketimbang kontuinitas bahan baku energi terbarukan berbasis singkong.

Jika upaya mendorong program energi alternatif tersebut tidak menyelesaikan fundamental tersebut di atas, maka program tersebut tidak akan lagi berjalan. Upaya yang didorong dan diperbaiki, selah satunya persoalan hubungan kelembagaan dengan upaya integrasi antarkementerian yaitu Kementerian Pekerjaan Umum, Kementerian Pertanian, Kementerian Kehutanan, dan BKSDA (Balai Konservasi Sumber Daya Alam) dengan tujuan membuat irigasi yang berasal dari Sungai Cimanuk atau sumber air pegunungan. Karena tanpa adanya itu pertanian tidak berjalan dan tidak menjadi sektor andalan masyarakat. Potensi lahan pertanian dan kebun di desa cukup besar karena mencapai 200 Hektar. Persoalan kurang suburnya lahan dan terbatasnya lahan menyebabkan tidak semua orang dapat mengarap tanah. Untuk itu sektor lain yang non-pertanian (pekerjaan buruh bangunan, usaha jasa, pedagang) menjadi sandaran hidup dengan pergi ke kota. Upaya yang menjadi fokus untuk 
dilakukan perbaikan juga ialah sistem pengolahan tanah dan kepemilikan lahan serta tenaga kerja berbasis pertanian. Tentu dengan melihat dan memahami kondisi sosial, budaya, ekonomi, dan ekologis.

Program pemerintah yang mendorong energi terbarukan berbasis singkong belum secara konsisten mendorong perlakuan terhadap tanah, tanaman, dan pemeliharaan namun lebih pada aspek teknis dan infrastruktur. Aspek struktural dan budaya masyarakat yang tidak dilihat sebagai hal mendasar untuk dipahami lebih dahulu. Upaya perbaikan strutural yang meliputi pembagian tanah yang sesuai dengan kebutuhan orang yang berprofesi menjadi petani, sehingga mengurangi jumlah buruh tani tanpa lahan. Desa semustinya dapat menjadi tempat yang nyaman untuk hidup dan bekerja terutama bagi masyarakat setempat.

Dalam hal itu energi baru dapat ditempatkan sebagai motor penggerak di sektor pertanian atau jasa di perdesaan. Penggunaan energi harus merupakan input sektor pertanian. Asupan energi di bidang pertanian meliputi empat kategori, yaitu energi yang terkandung (embodied) pada input pertanian (bibit, pupuk, agrokimia pemeliharaan lain, termasuk energi untuk pengemasan dan pengangkutannya), energi yang langsung digunakan, energi tenaga kerja (termasuk untuk pengangkutan tenaga kerja), dan energi yang terkandung pada alat atau mesin pertanian (energi modal atau capital energy). Kolaborasi itu yang dibutuhkan untuk mengerakan ekonomi pedesaan sebagai suatu momentum revitalisasi pembangunan yang menginternalisasi energi antara pertanian dan masyarakat perdesaan. Masyarakat perdesaan harus mampu berperan sebagai penyedia energi yang tidak lagi hanya sebagai pemakai.

\section{Saran}

Saran peneliti sebagai langkah yang harus dilakukan melalui penataan terkait persoalan pada beberapa aspek, yaitu antara lain:

1. Perhatian pada distribusi dan redistribusi tanah-tanah yang berperan sebagai mobilisasi sumberdaya yang selama ini hanya dijadikan objek spekulasi atau objek yang terbengkalai dan tidak produktif atau diperuntukan sebagai lahan eksploitatif. Pertanian harus pro terhadap semua lapisan masyarakat terutama petani tanpa lahan. Dengan memegang teguh keadilan sosial dan prinsip kesejahteraan bersama, bahwa tanah tidak lagi merupakan hak bagi segelintir orang yang memiliki uang saja. Orang yang memang mau berusaha di sektor pertanian harus didukung dan diberikan fasilitas sesuai dengan kebutuhannnya. Perbaikan sistem agraria merupakan landasan penting bagi penguasaan atas sumberdaya di tangan masyarakat lokal yang akan mempunyai dampak luas terhadap aspek sosial budaya.

2. Mengatasi persoalan ekologi dengan melakukan langkah-langkah penanggulangan kerusakan sumber daya alam dan pencemaran lingkungan di pedesaan sebagai suatu gerakan sosial. Menata dan memperkuat kembali akses dan kontrol masyarakat terhadap sumbersumber alam dengan mempertimbangkan aspek historis, budaya, kelembagaan, dan hukum yang hidup di masyarakat. Kerusakan dan pencemaran lingkungan dan perubahan konstelasi ruang (pemukiman, lahan konservasi, dan pertanian) telah membuat sulitnya kondisi air dan berubahnya karakteristik tanah oleh karena pemakaian unsur kimiawi di dalam pengolahan tanah. Hal itu juga mendorong titik dimana alam sudah jenuh dan membuat tanaman tidak tumbuh dengan baik. Lebih lanjut membuka ruang kewenangan pengelolaan sumber daya alam kepada masyarakat lokal sesuai dengan kapasitas kelembagaan dan kebutuhan masyarakat setempat. Serta meredefinisi gerakan pertanian yang alami dan tidak rakus mengeksploitasi lahan tanpa mempertimbangkan daya dukungnya. Hal tersebut akan membuat pemanfaatan sumber daya alam menjadi bersifat lebih adil dan berkelanjutan.

3. Mengatasi persoalan sosial-ekonomi dengan merevitalisasi sektor pertanian berbasis ekologi sebagai tumpuan kemajuan masyarakat desa dengan membuka akses informasi, pengetahuan, proses pembelajaran, dan bantuan yang berorientasi pada masyarakat luas dengan partisipatif. Kerangka edukasi lokal juga menyatu kepada aspek pemberdayaan yang dilakukan, seraya menumbuhkan minat pada pengembangan potensi lokal dengan melibatkan generasi muda progresif yang pro perubahan dan kesejahteraan. Hubungan dialogis dan komunikatif harus senantiasa dikembangkan dengan mengurangi kecurigaan dan berusaha memahami kelebihan dan kekurangan masingmasing. Dengan begitu hubungan antar individu di dalam komuniti memilik ruh dan keeratan yang relatif dapat berkolaborasi. 
4. Aspek budaya melalui kegiatan revitaliasi budaya. Langkah tersebut dapat menjadi pemersatu bagi semua individu di dalam masyarakat agar kesenjangan dan ketimpangan dapat diminimalisasi. Konsep saling tolong menolong, jaminan sosial bagi masyarakat desa yang kurang mampu, dan sampai kepada proteksi ketahanan internal dari gempuran budaya luar. Hal itu menjadi penting untuk digali kembali sebagai landasan tegaknya kemandirian di segala sektor, baik energi maupun pangan yang berlandaskan kepada keselarasan budaya.

Perbaikan-perbaikan pada aspek itu diharapkan menjadi harmonisasi bagi suatu perubahan yang mendasar di perdesaan. Hal terpenting yang dilakukan jika program-program apa pun yang ingin diwujudkan dan berlangsung musti melibatkan masyarakat di segala lapisan. Pelibatan masyarakat di segala lapisan juga musti disertai pendampingan yang terus dilakukan dalam kurun waktu tertentu sehingga program dapat berjalan dengan baik.

Pembenahan pertanian lebih dahulu secara menyeluruh diharapkan menjadi jalan keluar sulitnya sektor tersebut untuk berkembang. Jika itu tidak terselesaikan, niscaya praktik pengembangan bioetanol berbasis singkon atau tanama lainnya akan mengalami hambatan dan kegagalan kembali. Lebih lanjut, karakter bantuan yang sifatnya elitis harus berubah menjadi parsitipatif agar kesenjangan tidak semakin melebar. Hubungan patronase antaraelit di pemerintahan pusat dan desa yang diwariskan zaman orba harus dihilangkan. Hal itu yang menyebabkan bagaimana hubungan antara penguasa dan masyarakatnya tidak harmonis, saling curiga, dan jatuh menjatuhkan. Pranata sosial pedesaan yang kaya akan nilai kerukunan, musyawarah, dan dialogis harus direvitalisasi dan dibangun kembali. Agar arah pengembangan masyarakat menemui titik terang kembali sebagai pendorong inisiatif local yang bersifat inklusif.

\section{DAFTAR PUSTAKA}

Alwasilah, A. Chaedar. (2002). Pokoknya Kualitatif: Dasar-Dasar Merancang dan Melakukan Penelitian Kualitatif. Bandung: Pustaka Jaya.

Anonim. (2011). "Stok BBM Indonesia 20 hari dinilai kurang". Diakses tanggal 24 Februari dari: arsipberita.com
Antlöv, Hans. (2002). Negara Dalam Desa: Patronase Kepemimpinan lokal. Yogyakarta : Lappera Putaka Utama.

Bennett, John William. (1976). Adaptation and Social Process dalam The Ecological Transition: Cultural Anthropology and Human Adaptation. New York: Pergamon Press Inc.

Boomgaard, Peter. (2004). Anak Jajahan Belanda: Sejarah Sosial dan Ekonomi Jawa 1795-1880. Jakarta: Penerbit Djambatan dan KITLV.

Breman, Jan dan Wiradi, Gunawan. (2004). Masa Cerah dan Masa Suram di Pedesaan Jawa. Jakarta: Pustaka LP3ES.

Cahyono, M. Sigit. "Meluruskan Kembali Blue Print Energi Indonesia". Kedaulatan Rakyat, 17 Juni 2009,

Ekadjati, Edi S. (1995). Kebudayaan Sunda: Suatu Pendekatan Sejarah. Jakarta: Pustaka Jaya.

Geertz, Clifford. (1983). Involusi Pertanian: Proses perubahan Ekologi di Indonesia. Jakarta: Bhratara Karya Aksara.

Hanafi, Abdillah. (1981). Memasyarakatkan IdeIde Baru. Surabaya: Usaha Nasional.

Hardesty, Donald L. (1977). Ecological Anthropology. New York: John Wiley \& Sons Inc.

Hohnholz, Jürgen H. (1986). Geografi Pedesaan: Masalah Pengembangan Pangan. Jakarta: Yayasan Obor Indonesia.

International Energy Agency. (2008). Energy Policy Review of Indonesia. France: IEA.

Koentjaraningrat. (1984). Masyarakat Desa Di Indonesia Masa Ini. Jakarta: Lembaga Penerbit Fakultas Ekonomi Universitas Indonesia.

Maulidia, Martha. (2009). "Biofuel/ Bahan Bakar Nabati”. Diakses dari http://iklimkarbon.com/

Miles, Matthew B., dan A. Michael Huberman. (1992). Analisis Data Kualitatif: Buku Sumber tentang Metode-metode Baru (terjemahan oleh Tjetjep R. Rohidi). Jakarta: UI Press.

Nurlaila, Ida. (2007). Transformasi Kepranataan Sosioteknis dalam Perspektif Desa Mandiri Energi (Kasus Desa Mandalasari, Kadungora Kabupaten Garut). Tesis. PMSP-ITB.

Sofianto, Kunto. (2001). Garoet Kota Intan: Sejarah Lokal Kota Garut Sejak Zaman Kolonial Belanda Hingga Kemerdekaan. Jatinangor: Alqaprint.

Winarno, Budi. (2008). Gagalnya Organisasi Desa Dalam Pembangunan Di Indonesia. Yogyakarta: Penerbit Tiara Wacana. 